DOI: 10.19195/0137-1150.167.3

\author{
IRINA RAIKOVA
}

Московский городской педагогический университет, Rosja

\title{
Русские загадки о смерти, покойнике, погребении в межкультурном контексте
}

Танатологические образы и мотивы в народной культуре и фольклоре распространены и значимы. Достаточно вспомнить похоронно-поминальный обрядовый комплекс, призванный обеспечить „правильный” переход человека в новое, загробное, существование и регулировать его связь с миром живых; святочное обрядовое ряженье „в покойника”, когда смерть соседствует со смехом; парадоксальные для современного восприятия „смертные" колыбельные песни; смерть и ее преодоление в волшебных сказках; былички о „ходячем” покойнике и о других персонажах с несчастливым концом (когда встреча человека с мифологическим существом приводит к гибели человека); гадания и снотолкования, предвещающие смерть; детские страшилки, порожденные страхом и интересом ребенка к тайне смерти; баллады об убийствах и запоздалом раскаянии; духовные стихи о расставании души с телом, о посмертном воздаянии; пословицы и поговорки о жизни и смерти и т. д.

В этом ряду загадкам принадлежит особое место. Как один из архаичных, но до сих пор востребованных, неувядающих жанров фольклора, причем жанр наиболее универсальный с точки зрения этнокультурных, возрастных, гендерных и социальных характеристик среды, в которой он бытует, загадка обращена к важнейшим вопросам человеческого бытия и в то же время охватывает все его стороны, вплоть до малейших деталей. Для древнего человека „загадка была, видимо, существенным элементом ритуальных текстов космогонического характера, связанных с установлением состава макро- и микрокосма, ее ответы отсылают «к алфавиту мира»"1. Связь загадки и смерти прослеживается и в том, что загадки у многих народов, например, в Эстонии и Ингерманландии, было принято

\footnotetext{
${ }^{1}$ А. В. Юдин, Ономастикон восточнославянских загадок, Москва 2007, с. 9-10.
} 
загадывать на закате, в начале зимы, когда поминали усопших, у жителей Филиппин - во время ночного бдения у гроба ${ }^{2}$.

Особая роль танатологических образов и мотивов в загадке подтверждается их присутствием в обеих ее частях. Как известно, загадка - текст, имеющий две обязательные структурные части: образная замена/заместительный концепт/заместительная номинация/,вопросная” часть — и отгадка/,ответная” часть/денотат/загаданный объект.

\section{Танатос как отгадка (денотат) загадки}

Загадки с отгадкой „смерть” разнообразны, но самая известная в русском корпусе текстов — с птичьей символикой. Орнитологические и танатологические символы в фольклоре тесно связаны: птица - вестница смерти, посредник между этим и тем светом, воплощение души умершего, его посмертное обличье и т. п. Смерть принимает орнитоморфный облик это Птица Юстрица/Юрица/Веретеница/Веретено/утка/орел/сова/голубь/ ворон/птица немилостивая/ужасная, которая сидит на дубу (реже на столбе /на плоту/на престоле), наделенном причудливыми определениями (псевдотопонимическими) - таратынском, сарацинском, веретенском и др. „На мировом древе или древе жизни место птицы - на его вершине"3. В ряде вариантов дуб в свою очередь находится в сакральном локусе, известном по заговорам — „на море на Окияне, на острове на Буяне”. Эта важная птица, подобно некоторым эпическим героям, „хвалится, выхваляется” / „сама себе дивуется",

\footnotetext{
Что все видала,

Всего много едала.

Видела царя в Москве,

Короля в Литве,

Старца в келье,

Дитя в колыбели;

А того не едала,

Чего в море недостало 4 .
}

Этимология имени Юстрица/Юрица неясна, ее соотносят со словами „юркий” - 'быстрый, верткий’ и „юр” - 'открытое место, где погода юрит, где нет затишья; бойкое место’. Имя Веретено/Веретеница Александр Юдин объясняет (натянуто, по его словам) „традиционным использованием идеи вращения в таких метафорических сочетаниях, как круговорот времени, жизненный круг и т. п., определенным [...] родством слов время

2 Н. А. Лавонен, Карельская народная загадка, Ленинград 1977, с. 16-17.

${ }^{3}$ Мифы народов мира. Эничиклопедия, т. 2, К-Я, гл. ред. С. А. Токарев, Москва 1988, c. 346 .

${ }^{4}$ И. А. Худяков, Великорусские сказки. Великорусские загадки, Санкт-Петербург 2001, c. 435 . 
и вертеть"5. На наш взгляд, вращение - это и превращение, смерть оборачивается, принимая разные облики (ср.: диалектные синонимы слова „Превратиться” — „перевернуться”, „обернуться”). Кроме того, веретено это не просто вращающийся предмет, а древнейшее приспособление для прядения, так что можно говорить и о символике прядения и пряжи, нити человеческой жизни, явно в тексте не выраженной, а отзывающейся лишь в этой номинации. Тогда птица Веретено/Веретеница — русская параллель древнегреческим мойрам и римским паркам.

Поедание птицей-смертью, очевидно, - инициационный мотив (вспомним сказочную избушку на курьих ножках). В ряду виденного и поедаемого интересна этническая деталь - „короля в Литве”, расширяющая охват объектов географически. По вариантам даются условно-фольклорные ряды „царь, царица, красная девица” или „царь, царевич, король, королевич” (частые в других загадках и в иных жанрах фольклора, например в считалке), реже ,щука/рыба в море, заяц в норе, зверь в поле” - расширение за счет царства животных. Поедание по вариантам заменено более нейтральными формулами: „ее никто не уймет”, „никто от нее не отвертится (еще раз вспомним номинацию Веретено) / не отвиляется”, „никого не боюсь”, „никто меня не пройдет" и др. В ряде вариантов вместо птицы в поле стоит дуб/столб, который невозможно обойти-объехать. Как бы то ни было, идея очевидна: смерть не жалеет никого; ни возраст, ни пол, ни национальность, ни социальный статус, ни праведная жизнь не могут от нее защитить.

В одном варианте птица села на престол и говорит со Христом, якобы он дал ей волю надо всеми (и далее опять ряд), что согласуется с народноправославным убеждением о подвластности смерти Богу (в другой загадке она „ниже Бога, выше царя”6). Впрочем, иногда, по народным верованиям, „«подчиненность» смерти двойственна: посылаемая Богом, она «дает отчет» Дьяволу", а то и вовсе действует по своему усмотрению7. Сравним в якутском тексте: „Нечто, что ни богу, ни человеку не подвластно”8 . Возвратимся к варианту загадки о птице. В нем есть исключение: „Не дал ты мне воли / Ни в лесе, ни в поле, / Ни на синем море” [с. 314]. Речь, вероятно, идет о вечности природы вообще: лес, поле, море не подвержены индивидуальной смерти, как отдельные живые организмы.

В другой группе вариантов птица не хвалится, а показана в деле: она срывает/щиплет цветы/яблоки с дерева и бросает/мечет в котел/в корыто/в яму. Образы ямы и корыта прямо отсылают к могиле и гробу (ср. загадку с от-

5 А. В. Юдин, Ономастикон..., с. 62.

6 Д. Н. Садовников, Загадки русского народа: Сборник загадок, вопросов, притч и задач, Москва 1995, с. 315. Далее цитаты из данного сборника приводятся по этому изданию с указанием страницы в скобках.

${ }^{7}$ М. Н. Власова, Энщиклопедия русских суеверий, Санкт-Петербург 2008, с. 481.

8 А. Н. Журинский, Загадки народов Востока: Систематизированное собрание, сост. А. В. Козьмин, Москва 2007, с. 246. 
гадкой „гроб”, вошедшую и в подблюдную песню, предвещающую смерть: „Стоит корыто, другим накрыто” [с. 325]). По законам „загадочного” парадокса действия птицы не приводят к результату: „В котле не прибывает (вар.: корыто не наполняет, яма полна не бывает), / И цветов не убывает" [c. 314-315]. В этой иносказательной картинке красиво передана идея круговорота жизни на земле, смены поколений, бессилия смерти умалить жизнь. Грустно то, что птица срывает цветы/яблоки без разбору. В другом тексте это более ясно выражено: „Кто ходит по горам и долам и берет ягоды зрелыя и незрелыя? (смерть)" [с. 315].

Денотатом загадок бывают покойник в гробу, гроб, похороны. Распространены загадки про покойника, как ни странно, с „гастрономической” образностью:

Деревянный пирог,

Начинка мясная [с. 325].

Идут лесом,

Поют куролесом,

Несут деревянный пирог

С мясом [с. 324].

Пирог мясной,

Корки деревянны 9 .

Думается, здесь речь идет вовсе не о чудовище-земле, питающемся человеческими трупами. Обратим внимание на близость к этому тексту загадки о младенце в колыбели: „Липова огибка, Мясной пирожок”10. Пирог, пирожок - нечто приготовленное, потому он символизирует субъект, „готовый” к новой жизни. Сравним в современном языке: новоиспеченный только что ставший кем-то, получивший новый статус. Интересно, что с пирожком сравнивает младенца и колыбельная песня: „Спи, ржаной каравай, пшенная калитка, ягодна наливка" ${ }^{11}$. Два лиминальных существа: только пришедшее из неведомого мира, стоящее на пороге нового, и уходящее в иной мир, подготовленное к этому. В народных представлениях это один и тот же „иной мир”. Предлагаем сравнить со снотолкованием: видеть себя беременной для пожилой женщины - к скорой смерти.

Пирожок - зерновой продукт. Зерно символизирует зарождение новой жизни, и продукты из него - едва ли не самые популярные в обрядовых трапезах славянских народов, как семейных, так и календарных: те же пирожки, блины, кутья, каша, печенье и др. В фольклоре, разумеется, это тоже

9 Русские народные загадки Пермского края: сборник фольклорных текстов с комментариями и истолкованиями, сост. И. А. Подюков, А. В. Черных, Санкт-Петербург 2012, с. 97.

10 Там же, с. 87.

11 С. М. Лойтер, Детский поэтический фольклор Карелии: исследование и тексты, Петрозаводск 2013, с. 105. Калитка здесь - название карельского национального лакомства, открытого пирожка с начинкой, обычно ягодной или пшенной. 
отражено; так, в упомянутых ранее „смертных” колыбельных говорится, что бабка на помин пирожков напечет.

Пирожки пекут в печи. Печь - самый мифологизированный из предметов обихода, одновременно сакральный центр и граница (имеет выход через дымоход) дома как модели вселенной. Кстати, поэтому у всех европейских народов есть разнообразные загадки с отгадкой „печь”. Символическую функцию печь выполняет, кроме прочего, и потому, что в ней готовится пища, т. е. природный, сырой продукт превращается в культурный, готовый объект, а дрова обращаются в пепел и дым, восходящий к небесам. Печь символизирует в одних обрядах материнское лоно, утробу, в других могилу, иной мир, а в некоторых - то и другое одновременно: в обряде допекания / перепекания (символически в печи) больного младенца якобы больной ребенок умирает - и рождается новый, здоровый.

В этих загадках перед нами пирог именно с мясной начинкой: человеческое тело, плоть названо мясом. Можно сравнить также с загадками о младенце, которого кормят грудью. В карельском тексте это выражено более ярко, чем в русском, усилено тройной тавтологией: „Мясистый мясистого ест (вар.: посасывает) на мясистом ларце (вар.: мясистой горке)"'12. По вариантам это „сырое” мясо - признак, противоречащий предмету замены (готовому пирожку) и намекающий на денотат. Деревянное/липовое второй такой признак, он указывает на необычность пирожка, приближая нас к отгадке. Однако иносказательность как сущностный признак загадки не позволяет сделать еще один шаг к отгадке и сказать о пирожке „с человеческим мясом”. Этот образ мы находим в другом жанре - детской страшилке, где о смерти, гробе, мертвеце говорится с установкой „страхопорождения”.

Печь и выпечка как человеческое сообщество фигурируют и в загадке с отгадкой „смерть”: „Печь день и ночь печет, а невидимка дошлую ковригу выхватывает” [с. 315]. По словарю Даля „дошлый”- спелый, зрелый, о печном - хорошо выпеченный, о человеке - опытный, знающий (ср.: дока), бывалый, „тертый калач"13. Эта загадка, по сравнению с вышеприведенными загадками о смерти-птице и ягодках зрелых и незрелых, оптимистична: смерть здесь выхватывает из жизни немолодых, зрелых, как бы готовых к смерти.

В другой распространенной загадке о покойнике указывает на его отличия от живых людей. В процессе похоронного обряда он теряет признаки живого человека, он должен окончательно стать „иным”, сменив статус. Ключевым мотивом здесь является мотив дороги: это и реальная в рамках похоронного ритуала дорога от дома до могилы, по которой перемещается покойник в сопровождении близких; это и символический путь, который

12 Карельские народные загадки, изд. подгот. Н. А. Лавонен, Петрозаводск 1982, с. 74.

13 В. И. Даль, Толковый словарь русского языка. Современная версия, Москва 2000, с. 219. 
проделывает главный участник любого обряда перехода, отделяясь от „,воего” мира и переходя в ,иной”.

Встал я не ладно (не так),

Умылся (по вар.: вымылся) не ладно,

(по вар.: обулся не так,

Оделся не так,

Сел не так),

Поехал не так,

Заехал (по вар.: завалился, опружился) в ухаб,

Не выехать (по вар.: не выстать, не вылезти) никак [с. 326-327].

$\cdots$

Поехал не так, в яму - бряк ${ }^{14}$.

Традиционные этнографические особенности выбора и изготовления „смертной” одежды и обуви, подчеркивающие ее „инакость”, предназначенность для мертвого (ее шили на „живую” нитку, держа иголку от себя и даже левой рукой, застегивали наоборот и т. п.) описывает в своей монографии Альберт Байбурин ${ }^{15}$. При всей недосказанности загадка точна, знатокам похоронных обычаев ее намеки ясны. Но дело не только в иной одежде: человек, отправляющийся в поездку на лошадях, встал и сел „не так” (читай: не встал и не сел, а лёг на телегу или сани, как не делают живые), умылся и поехал тоже не так - хотя бы потому, что не сам. Итог цепочки „не таких" действий - ухаб/яма, т. е. этот горе-ездок и дороги не разбирает, как бы уже не разбираясь в путях живых людей (в одном из вариантов: „ничего не видит кругом”). „Дорога в мир мертвых, - пишет А. К. Байбурин, не должна совпадать с путями живых"16.

Кладбище как разгадка загадки также описывается через отрицание признаков: это заселенное село, где „петухи не поют и люди не встают”. В варианте „по утрам петухи поют, а люди не встают”17 (сельское кладбище зачастую находится в селе, рядом с жилыми домами, и пение петухов там слышно). Описание напоминает „антимир” как локус славянских заговоров, „пустое место”, куда прогоняют - подальше от живых людей - болезни и несчастья: „где люди не ходят и не бывают, где птицы не летают, где звери не заходят" (так называемая формула отсылки).

Гроб показан тоже как весьма странная вещь, не обладающая признаками вещей, которыми пользуются живые. Загадка, имеющая международное распространение:

Сработан кафтан не на себя,

Куплен не про себя,

14 Русские народные загадки Пермского края..., с. 97.

15 А. К. Байбурин, Ритуал в традиционной культуре. Структурно-семиотический анализ восточнославянских обрядов, Санкт-Петербург 1993, с. 108-109.

16 Там же, с. 113.

17 Русские народные загадки Пермского края..., с. 181. 
А кем изношен,

Тем не видан [c. 325].

Кто делает — тот не хочет (вар.: не желает; тому не нужен),

Кому делают — тот не знает [с. 326].

Есть о гробе еще одна очень интересная загадка, тонко воспроизводящая настроение родственника, который имеет с ним дело: „Тяп-тяпком, / Погодя маленько, / Хлоп замком (гроб)". Нельзя не согласиться с Иваном Худяковым, который публикует и комментирует ее: „Гроб делается как бы нехотя, с горем; а как придет время зарывать в землю, то обыкновенно захлопывается очень скоро"18. Действительно, во всем похоронном обряде налицо сначала некая заторможенность, неохота, родственники будто специально хотят „погодить”, оттянуть момент окончательного прощания, а потом всё резко заканчивается с закрытием крышки гроба. Этот стук, „хлоп” самый психологически тяжелый момент, наверное потому, что с телом ведут себя уже как с вещью, некой кладью.

С другой стороны, это „тяп-тяпком” (ср.: „сделать тяп-ляп”) объясняется и чисто ритуальными традициями. Вещи для покойника специально делались незавершенными, как бы „недоделанными”. „Гроб никогда тщательно не обтесывался, его обтеска делалась нарочито грубо", - пишет А. К. Байбурин и предлагает двоякую мотивировку семантики этого обычая: как выражение „инакости” „чужого” мира (что в земном мире не годится, то годится там) и „в связи с идеей продолжения жизни” (там будет доделано) ${ }^{19}$.

Тонкости погребального ритуала кратко и поэтично, с использованием ряда интересных окказионализмов, тавтологически сочетающихся с глаголами, отражены и в популярных загадках, отгадка которых — „похороны”. Это целая движущаяся и многоголосая картинка. Из разных вариантов: „певунчики поют, воимчики поют (певчие, от слов «Во имя Отца и Сына...». - И. Р.), ревунчики ревут, текунчики текут, бегунчики бегут, пометушки метут, поскребушки скребут" [с. 325]. По контрасту с этой множественностью, движением, эмоциями окружающих покойник один, неподвижен, нем: „не дышит, не пышет, в сухом дереве лежит”; „не пыхнет, не дыхнет, не ворохнется”, „не пищит, не визжит, не шевельнется” [с. 324-325]. По вариантам он вообще как бы слит с сухим деревом и назван окказионализмом „,суходерец”: „суходерца несут” ${ }^{20}$. Он таким образом отделен от других участников обряда.

Наконец, есть загадка с отгадкой „смерть”, построенная на игре различными значениями слова „загадка”: это и малый поэтический жанр фольклоpa, но это и тайна вообще. Текст звучит так: „Загадка без разгадки (смерть)”

\footnotetext{
${ }^{18}$ И. А. Худяков, Великорусские сказки..., с. 408.

19 А. К. Байбурин, Ритуал..., с. 109.

${ }^{20}$ И. А. Худяков, Великорусские сказки..., с. 422.
} 
[c. 315]. Говоря о сложности, глубине, загадочности самого жанра загадки, В. Н. Топоров пишет об этом тексте: „это и высказывание о самой загадке, сделанное как бы вне «загадочной» формы, о загадке в самой ее бесконечно углубляющейся по мере ее разгадывания сути..."21.

\section{Мотив смерти в образной замене загадки}

Наиболее устойчиво мотив смерти связан с загадыванием природных объектов, в этом реализуется архаичная идея циклического умираниявоскрешения природы, широко представленная в мифах и календарной обрядности.

\footnotetext{
Летит - молчит,

Лежит - молчит,

Когда умрет,

Тогда заревет ${ }^{22}$.
}

Парадоксальность - неотъемлемая черта загадки - состоит здесь в том, что в реальности люди и животные, напротив, бывают шумными при жизни и молчат после смерти. Здесь зашифрованы снег и вешние воды как иная ипостась снега (умирающего и рождающегося в новом качестве). Вариант этой загадки удачно комментируют составители пермского сборника: „Глагол «реветь» как нельзя более точно передает народное восприятие вешней стихии, во время которой в природе как будто бы просыпается дикое начало, высвобождаются хтонические силы"; таким образом загадка апеллирует к языческим представлением о весне как «начале начал» ${ }^{23}$. Наблюдения за сезонными превращениями и функциями снега характерны для этнокультурного сознания человека средней полосы:

Зимой греет,

Весной тлеет,

Летом умирает,

Осенью оживает.

Увидел мать -

Умер опять [с. 273].

Близкие загадки о метаморфозах жизни и смерти водной стихии есть у многих народов мира, культ воды для которых - один из значимых. Так, ряд текстов с отгадкой „лёд на реке или на озере” есть в карельском фоль-

${ }^{21}$ В. Н. Топоров, Из наблюдений над загадкой, [в:] Исследования в области балтославянской духовной культуры:: Загадка как текст - 1, отв. ред. Т. М. Николаева, Москва 1994, c. 11.

22 Чудеса в решете. Вся русская загадка, сост. Д. Н. Садовников, Москва 2015, с. 273. Далее цитаты из данного сборника приводятся по этому изданию с указанием страницы в скобках.

${ }^{23}$ Русские народные загадки Пермского края..., с. 198. 
клоре, наиболее развернутая такова: „От матери рождается и без матери рождается, умирает в муках и без отпевания попом, при жизни чист, как алмаз, светит красиво, как луна" 24 . Отметим любование льдом и сожаление по поводу его таяния - приметы северного менталитета. С философским спокойствием звучит похожая загадка алтайских народов, заключающая предельно обобщенное иносказательное описание: „Первый умрет - второй оживет, второй умрет - первый оживет (лето - бежит вода, наступит зима - в лед превращается)" 25 .

В другой более редкой русской загадке изображается не смерть снега весной, а, напротив, осенне-зимнее умирание самой матушки земли, природы, а снег здесь - атрибут погребального обряда, он уподоблен савану для покойницы-земли (тоже белого цвета и покрывает ее полностью): „Не хилела, / Не болела, / А саван надела (земля под снегом)" [с. 275]. В древности, как известно, белый, а не черный цвет был цветом траура. И сама персонифицированная смерть как демонологическое существо в быличках, легендах, сказках славянских народов, как заключает Людмила Виноградова в результате сравнительно-исторического исследования, предстает в облике сухой и бледной „женщины в белом”, часто исполнители уточняют: „белая как снег” 26.

Впрочем, смерть природы мыслится как временная. Оптимистичная загадка о земле, в которой однозначно утверждается невозможность ее окончательной смерти, есть у карельского народа: „Родилось, не умрет (земля)”27.

Детали-атрибуты похоронного обряда ярко, даже зловеще показаны и в загадке, представляющей собой картину грозы: „Гроб плывет, мертвец ревет, / Ладан пышет, свечи горят (Гром, молния, туча)"28. Снова перед нами образ „нетихого”, ревущего покойника (здесь уже в него превращается гром), а туча, движущаяся по небу, уподоблена одновременно гробу и лодке, т. к. этот необычный небесный гроб не несут и не везут, а он „плывет”. Метафора „гроб — лодка, ладья” частотна у многих народов: эти предметы сходны по форме; гроб, по древним представлениям, — это средство „перемещения на тот свет, который отделен от мира живых рекой"29.

Стихия огня также связана со смертью. В международной загадке, подробно рассмотренной еще сто лет назад А. Аарне, который нашел ее истоки в Древней Греции, огонь и дым уподоблены отцу и сыну, при этом дым, высоко взлетающий, изображен более шустрым, чем огонь (опережающим

${ }^{24}$ Н. А. Лавонен, Карельская народная загадка..., с. 184.

${ }^{25}$ К. Е. Укачина, Алтайские народные загадки: Исследование, Горно-Алтайск 1984, c. 34 .

26 Л. Н. Виноградова, Мифологический аспект славянской фольклорной традиции, Москва 2016, с. 173-179.

${ }^{27}$ Карельские народные загадки..., с. 105.

28 Русские народные загадки Пермского края..., с. 23.

29 Там же, с. 197. 
отца). У русских: „Отец не рождался, а сын уж на крыше сидит”30; у карелов: „Отец только родился, а сыновья уже в лес идут”31; у коми: „Отец еще обувается, а сын уже вокруг города ходит" 32 . Логическое, но парадоксальное продолжение, связывающее рождение и смерть, находим в другом карельском варианте: „Отец только родился, а сын уже на небесах”33.

Водную стихию как смертельно опасную для человека рисует загадка о лодке с редким продолжением:

Еду, еду -

Ни пути, не следу.

Смерть подо мной,

Бог надо мной [c. 213].

В ней остро ощущается беспокойство человека, как бы застрявшего между водой и небом и надеющегося только на Бога. Этот текст близок загадкам из бытовых сказок о мудрой деве-отгадчице, вошедшим и в древнерусскую повесть о Петре и Февронии, в которых иносказательно говорится об опасных профессиях, в частности занятии древолаза: он сквозь ноги смотрит в лицо смерти.

Лодку и другие опасные предметы и занятия, с ними связанные, загадывают в вариантах следующей загадки старообрядцы Литвы: „Круть, верть, под черёпкою (вар.: в черепушке, на черпачке) - смерть (лодка, мельница, жарят рыбу)"34.

Есть в корпусе русских загадок любопытные тексты о кабаке - как о социальном бедствии, которое может привести к человеческой смерти (вообще, социально-экономические реалии - редкость в качестве объектов загадывания):

На поле, полище

Стоит зеленище;

В том зеленище:

Сусло, масло,

Легость, болесть

И смерть недалеко [c. 147].

Загадка весьма вариативна — „стоит деревище/теремище/голенище/ дуб дупляной/столб коротущий/долгий Антошка”, в нем „пакость, легость/ смелость, бодрость/скорбость и весель/боли да хвори". Однако все варианты предупреждают, что это причудливое „сооружение” с не менее удивительным, пестрым содержимым чревато смертью человеческой [c. 147-148].

${ }^{30}$ И. А. Худяков, Великорусские сказки..., с. 425.

${ }^{31}$ Н. А. Лавонен, Карельская народная загадка..., с. 52.

32 Коми народные загадки, сост. Ф. В. Плесовский, Сыктывкар 1975, с. 16.

${ }_{33}$ Карельские народные загадки..., с. 33.

34 Фольклор старообрядиев Литвы: тексты и исследования, т. 1, Сказки. Пословицы. Загадки, изд. подгот. Ю. Новиков, Вильнюс 2007, с. 540. 
Думается, танатологические образы и мотивы, зачастую неожиданные и смелые, в „вопросной” части текста загадки призваны удивить, взбудоражить воображение отгадчика.

Таким образом, загадки о смерти, покойнике, гробе, кладбище, похоронах и загадки с мотивами смерти, умирания в „заместительной” части органичны для жанра, т. к. смерть сама есть загадка, и самая трудная загадка. Они представляют Танатос фольклорный многомерно, подробно, серьезно, во многом универсально для традиций разных народов, с опорой на миф и культ. В преобразованном виде и художественной форме они воспроизводят эпизоды и предметные реалии похоронного обряда и других обрядов перехода. Загадки при этом выражают неизменную во все времена народную веру в то, что смерть физическая — не окончательный финал.

\section{Библиография}

Байбурин А. К., Ритуал в традиционной культуре. Структурно-семиотический анализ восточнославянских обрядов, Санкт-Петербург 1993.

Виноградова Л. Н., Мифологический аспект славянской фольклорной традиции, Москва 2016.

Власова М. Н., Энциклопедия русских суеверий, Санкт-Петербург 2008.

Журинский А. Н., Загадки народов Востока: Систематизированное собрание, сост. Козьмин А. В., Москва 2007.

Карельские народные загадки, изд. подгот. Н. А. Лавонен, Петрозаводск 1982.

Коми народные загадки, сост. Ф. В. Плесовский, Сыктывкар 1975.

Лавонен Н. А., Карельская народная загадка, Ленинград 1977.

Лойтер С. М., Детский поэтический фольклор Карелии: исследование и тексты, Петрозаводск 2013.

Мифы народов мира, Энциклопедия, т. 2, К-Я, гл. ред. С. А. Токарев, Москва 1988.

Русские народные загадки Пермского края: сборник фольклорных текстов с комментариями и истолкованиями, сост. И. А. Подюков, А. В. Черных, Санкт-Петербург 2012.

Садовников Д. Н., Загадки русского народа: Сборник загадок, вопросов, притч и задач, Москва 1995.

Топоров В. Н., Из наблюдений над загадкой, [в:] Исследования в области балто-славянской духовной культуры:: Загадка как текст - 1, отв. ред. Т. М. Николаева, Москва 1994.

Укачина К. Е., Алтайские народные загадки: Исследование, Горно-алтайск 1984.

Фольклор старообрядиев Литвы: тексты и исследования, т. 1, Сказки. Пословицы. Загадки, изд. подгот. Ю. Новиков, Вильнюс 2007.

Худяков И. А., Великорусские сказки. Великорусские загадки, Санкт-Петербург 2001.

Чудеса в решете. Вся русская загадка, сост. Д. Н. Садовников, Москва 2015.

Юдин А. В., Ономастикон восточнославянских загадок, Москва 2007.

Slavica Wratislaviensia 167, 2018

(C) for this edition by CNS 


\section{Russian folk riddles about death, dead and funerals in the context of folklore traditions of the world}

\section{Summary}

Subjects related to death, the dead and funerals, as well as the motive of "substitute" death, are a natural element of folk riddles, as death itself is the most difficult one to solve and the great unknown. Thanatos in Russian folk riddles is characterized by multidimensionality, great detail and atmosphere of tension, but also by universalism in relation to the traditions of different nations. The knowledge of death is based primarily on mythology and descriptions of various cults and rituals. These riddles are also an expression of the faith that has been preserved over the years, that physical death is not the end of human existence.

Keywords: folklore, riddle, death, myth, ritual

\section{Rosyjskie zagadki ludowe o śmierci, zmarłych i pogrzebach w kontekście tradycji folklorystycznych na świecie}

\section{Streszczenie}

Tematy związane ze śmiercią, zmarłymi i pogrzebami, a także z motywem śmierci „,zastępczej" są naturalnym elementem zagadek ludowych, jako że śmierć sama w sobie to wielka tajemnica i najtrudniejsza do rozwiązania zagadka.

Tanatos w rosyjskich zagadkach ludowych charakteryzuje się wielowymiarowością, cechuje go szczegółowość i atmosfera napięcia, ale też uniwersalizm w stosunku do tradycji różnych narodów. Wiedza o śmierci bazuje w nich przede wszystkim na mitologii oraz opisach rozmaitych kultów i rytuałów. Zagadki te stanowią również wyraz utrwalanej przez lata wiary w to, że śmierć fizyczna nie stanowi końca istnienia człowieka.

Słowa kluczowe: folklor, zagadka, śmierć, mit, rytuał 